\title{
PENDUDUK, ANGKATAN KERJA, PENYERAPAN TENAGA KERJA PADA SEKTOR USAHA MIKRO KECIL MENENGAH (UMKM) DI JAWA BARAT
}

\author{
Siti Marti’ah \\ Program Studi Informatika, Fakultas Teknik dan Ilmu Komputer \\ Universitas Indraprasta PGRI Jakarta \\ Sitimartiah1@gmail.com
}

Dikirim:30 November 2020 Direvisi:12 Desember 2020 Dipublikasikan:31 Desember 2020

\begin{abstract}
ABSTRAK
Penelitian ini bertujuan untuk mengetahui pengangguran dan ketenagakerjaan, dan Usaha mikro Kecil dan menengah di Jawa barat. Metode Penelitian ini termasuk Penelitian deskriptif kualitatif, hasil dari penelitian adalah dengan penduduk 49.02 Juta. Dengan jumlah tersebut laju penduduk semakin pesat dan berpengaruh terhadap masalah angkatan kerja, serapan tenaga kerja pada sektor sektor usaha. Tingkat Partisipasi Angkatan 2017 sebesar 63,34. Tahun 2018 sebesar 62,92 mengalami penurunan 0,42 dan pada 2019 TPAK sebesar 65,07 naik sebesar 2.15. Jumlah tenaga kerja sektor Industri sebesar 3. 723, 416 terdiri dari Industri Mikro dan kecil sebesar 1.455.352 dan Industri Besar dan sedang 2, 268064 . Untuk Penyerapan UMKM dengan penyerapan terkecil pada kota Cirebon dengan angka 8.652, sedangkan usaha menengah dan besar terkecil yaitu kabupaten penggandaran dengan angka 241. Penyerapan unit Mikro dan kecil Kabupaten Cirebon dengan total 1,455, 352 dan untuk menengah dan besar Bekasi dengan angka 2,268,064. Jumlah UMKM dan Industri Besar sebesar 584. 274 terdiri dari UMK sejumlah 574,175 dan Industri Besar dan sedang sebesar 10,099. Untuk industry Mikro dan Kecil dengan jumlah terkecil kota Cirebon dengan angka 3203 dan terbesar pada kota tasik Malaya sebesar 55,002, sedangkan usaha menengah dan besar dengan angka terkecil yaitu kabupaten penggandaran dengan angka 9. Penyerapan untuk menengah dan besar Bekasi dengan angka 2.503 Kota Bekasi
\end{abstract}

Kata Kunci : Penduduk, Angkatan Kerja, Serapan Kerja, Usaha

\section{A. PENDAHULUAN}

Dalam Sejarah ditunjukkan bahwa propinsi Jawa Barat merupakan provinsi pertama di Indonesia. Proyeksi penduduk jawa barat pada tahun 2019 mencapai 49,02 juta jiwa yang terdiri dari laki-laki 24,8 juta jiwa sedangkan perempuan sebanyak 24,2 juta jiwa yang merupakan suatu indikator bagi suatu Negara. Laju pertumbuhan penduduk yang sangat pesat akan berpengaruh tarhadap masalah pemerataan serta mutu dan relevansi kependudukan terutama dalam bidang ketenagakerjan. (Agustina, Syechalad, \& Hamzah, 2019). 


\section{Q JURAAA}

Vol 1, No. 2 (2020), Desember 2020

E-ISSN: 2746-2471, DOI:

Dalam pembangunan jawa barat tidak terlepas dengan masalah pengangguran dan ketenagakerjaan, Jawa barat membutuhkan sumber daya manusia yang mempunyai kualifikasi dan keahlihan tertentu. Berbagai sektor lapangan pekerjaan di buka setiap waktu mulai dari pertanian, perdagangan dan sektor-sektor lainnya, dalam hal ini jumlah angkatan kerja di provinsi jawa barat yang tidak seimbang dengan kesempatan kerja serta jumlah penduduk yang besar akan menghasilkan angkatan kerja yang besar pula. Angkatan kerja yang besar jika dapat dimanfaatkan dengan baik akan mampu meningkatkan kegiatan perekonomian yang pada akhirnya akan meningkatkan kesejahteraan masyarakat.

Masalah angkatan kerja dapat dicapai apabila angkatan kerja yang tersedia terserap oleh kesempatan kerja. Kesempatan kerja merupakan keadaan yang menggambarkan ketersediaan lapangan pekerjaan di masyarakat. Jumlah penduduk yang besar ditambah dengan tingginya laju pertumbuhan penduduk yang seharusnya menjadi pendorong peningkatan kegiatan ekonomi justru menjadi beban bagi pembangunan ekonomi. Akan tetapi tingkat pertumbuhan penduduk tinggi itu tidak diiringi oleh pertumbuhan kesempatan kerja.Perekonomian dalam negeri Indonesia memiliki potensi besar dalam wujud usaha, mikro, kecil, dan menengah (UMKM) dan besar. Pengembangan UMKM dan besar dapat menjadi sumber pertumbuhan ekonomi baru sekaligus mendorong perekonomian daerah. Dari latar belakang diatas penulis tertarik untuk menganalisis sebarapa besar serapan penduduk, angkatan kerja, kesempatan kerja dengan Usaha mikro kecil dan menengah.

\section{B. KAJIAN PUSTAKA Penduduk}

Jumlah penduduk dalam pembangunan ekonomi suatu daerah merupakanpermasalahan mendasar, Karena pertumbuhanpenduduk yang tidak terkendali dapatmengakibatkan tidak tercapainya tujuan pembangunan ekonomi yaitu kesejahteraan rakyat serta menekan angka kemiskinan (Didu \& Fauzi, 2016). kecenderungan umum penduduk suatu negara untuk tumbuh menurut deret ukur yaitu dua-kali lipat setiap 30-40 tahun. Sementara itu pada saat yang sama, karena hasil yang menurun dari faktor produksi tanah, persediaan pangan hanya tumbuh menurut deret hitung. (Arsyad, 2004).

Oleh karena pertumbuhan persediaan pangan tidak bisa mengimbangi pertumbuhan penduduk yang sangat cepat dan tinggi, maka pendapatan perkapita (dalam masyarakat tani didefinisikansebagai produksi pangan perkapita) akan cenderung turun menjadi sangat rendah, yang menyebabkan jumlah penduduk tidak pernah stabil, atau hanya sedikit di atas tingkat subsiten.(Sadono Sukirno, 2002). menunjukan bahwa pertumbuhan penduduk yang pesat di negaraberkembang menyebabkan tingkat kesejahteraan masyarakat tidak mengalami perbaikanyang berarti dan dalam jangka panjang akan mengalami penurunan kesejahteraan sertameningkatkan jumlah penduduk miskin.

\section{Angkatan Kerja dan Tenaga Kerja}

Menurut Undang-Undang No. 13 Tahun 2003, ketenagakerjaan adalah segala sesuatu yang ada kaitannya dengan tenaga kerja baik itu sebelum, selama, dan sesudah kerja. Ketenagakerjaan adalah suatu hal yang menyangkut soal tenaga kerja dan hal-hal lain 


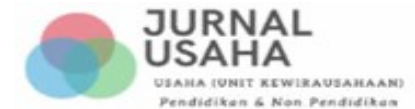 \\ Vol 1, No. 2 (2020), Desember 2020 \\ E-ISSN: 2746-2471, DOI:}

terlibat di dalamnya, seperti kesempatan kerja, gaji, kualitas kerja, pemenuhan hak pensiun, dan lain sebagainya.

Tenaga kerja merupakan penduduk pada usia kerja yaitu antara 15 sampai 64 tahun. Penduduk dalam usia kerja ini dapat digolongkan menjadi dua, yaitu angkatan kerja (Labor force) dan bukan angkatan kerja. (Irawan \& Suparmoko, 2002). Penduduk dalam usia kerja ini dapat digolongkan menjadi dua, yaitu angkatan kerja (Labor force) dan bukan angkatan kerja. Angkatan kerja tergolong dari tenaga kerja yang bekerja dan menganggur atau mencari pekerjaan.

Kesempatan kerja adalah jumlah lowongan pekerjaan yang dapat ditampung olehsuatu unit usaha supaya dapat menghasilkan output tertentu sedangkan kemampuanlapangan kerja menyerap jumlah tenaga kerja yag memenuhi kriteria pada lapangankerja itu di sebut penyerapan tenaga kerja. (Kuncoro, 2002)

\section{Usaha Mikro, Kecil dan Menengah (UMKM)}

Ada dua definisi UMKM yang dikenal di Indonesia. Pertama, definisi usaha menurutUndang -undang (UU) Nomor 20 Tahun 2008 tentang Usaha Mikro, Kecil dan Menengah. Menurut UU ini, usaha kecil didefinisikan sebagai kegiatan ekonomi produktif yang berdiri sendiri, yang dilakukan oleh orang perorangan atau badan usaha yang bukan merupakan anak perusahaan atau bukan cabang perusahaan yang dimiliki, dikuasai, atau menjadi bagian, baik langsung maupun tidak langsung, dari usaha menengah atau usaha besar, serta memenuhi kriteria antara lain: kekayaan bersih Rp.50 juta sampai Rp.500 juta tidak termasuk tanah dan bangunan tempat usaha, atau memiliki hasil penjualan tahunan Rp.300 juta sampai Rp.2,5 miliar. (Hafni \& Rozali, 2017)

\section{METODE PENELITIAN}

Penelitian ini menggunakan Penelitian deskriptif kualitatif adalah penelitian yang menggambarkan atau melukiskan objek penelitian berdasarkan fakta-fakta yang tampak atau sebagaimana adanya. (Nawawi \& Martini, 1996).Penelitian kualitatif adalah penelitian dimana peneliti ditempatkan sebagai instrument kunci, teknik pengumpulan data dilakukan secara penggabungan dan analisis data bersifat induktif (Sugiyono, 2010).

Jenis dan Sumber Data

Peneliti menggunakan data sekunder dalam penelitian ini. Data sekunder merupakan data primer yang telah diolah lebih lanjut dan disajikan baik pihak pengumpul data primer maupun oleh pihak lain (Husein Umar, 2001). Data yang diperoleh adalah data time series yaitu data dari suatu fenomena tertentu yang didapat dari beberapainterval waktu tertentu misalnya dalam waktu mingguan, bulanan, dan tahunan

Sumber data dalam penelitian ini diperoleh dengan cara mendownloadmelalui situs www.BPS.go.id. Dengan menggunakan data time series tahun 2017, 2018 dan 2019 terkait jumlah penduduk, angkatan kerja, tenaga kerja sector usaha mikro kecil, menengah dan besar di provinsi Jawa Barat (BPS, n.d.) 


\section{JURNAL USAHA \\ Vol 1, No. 2 (2020), Desember 2020 \\ E-ISSN: 2746-2471, DOI:}

\section{HASIL DAN PEMBAHASAN}

Dibawah ini adalah gambaran Penduduk di Jawa barat Dari hasil penelitian, didapatkan data jumlah penduduk di jawa barat yang dapat dilihat dari Tabel berikut :

Tabel 1. Jumlah penduduk Jawa Barat , 2017-2019

\begin{tabular}{lrrr}
\hline \multicolumn{1}{c}{ Jawa Barat } & 2017 & \multicolumn{1}{c}{2018} & \multicolumn{1}{c}{2019} \\
\hline Bogor & $5,715,009$ & $5,840,907$ & $5,965,410$ \\
Sukabumi & $2,453,498$ & $2,460,693$ & $2,466,272$ \\
Cianjur & $2,256,589$ & $2,260,620$ & $2,263,072$ \\
Bandung & $3,657,601$ & $3,717,291$ & $3,775,279$ \\
Garut & $2,588,839$ & $2,606,399$ & $2,622,425$ \\
Tasik Malaya & $1,747,318$ & $1,751,295$ & $1,754,128$ \\
Ciamis & $1,181,981$ & $1,188,629$ & $1,195,176$ \\
Kuningan & $1,068,201$ & $1,074,497$ & $1,080,804$ \\
Cirebon & $2,159,577$ & $2,176,213$ & $2,192,903$ \\
Majalengka & $1,193,725$ & $1,199,300$ & $1,205,034$ \\
Sumedang & $1,146,435$ & $1,149,906$ & $1,152,400$ \\
Indramayu & $1,709,994$ & $1,719,187$ & $1,728,469$ \\
Subang & $1,562,509$ & $1,579,018$ & $1,595,825$ \\
Purwakarta & 943,337 & 953,414 & 962,893 \\
Karawang & $2,316,489$ & $2,336,009$ & $2,353,915$ \\
Bekasi & $3,500,023$ & $3,630,907$ & $3,763,886$ \\
Bandung Barat & $1,666,510$ & $1,683,711$ & $1,699,896$ \\
Pangandaran & 395,098 & 397,187 & 399,284 \\
Kota Bogor & $1,081,009$ & $1,096,828$ & $1,112,081$ \\
Kota Sukabumi & 323,788 & 326,282 & 328,680 \\
Kota Bandung & $2,497,938$ & $2,503,708$ & $2,507,888$ \\
Kota Cirebon & 313,325 & 316,277 & 319,312 \\
Kota Bekasi & $2,859,630$ & $2,931,897$ & $3,003,923$ \\
Kota Depok & $2,254,513$ & $2,330,333$ & $2,406,826$ \\
Kota Cimahi & 601,099 & 607,811 & 614,304 \\
Kota Tasikmalaya & 661,404 & 662,723 & 663,517 \\
Kota Banjar & 182,388 & 182,819 & 183,110 \\
\hline Sumber : Badan Pusa & & &
\end{tabular}

Sumber : Badan Pusat Statistik.2020

Berdasarkan data diatas terlihat bahwa Jumlah penduduk Jawa Barat pada tahun 2017 sebesar 48, 03 jt, tahun 2018 sebesar 48,68 juta dan tahun 2019 sebesar 49,16 juta ini mengalami peningkatan dalam 3 tahun. Penduduk terbanyak yaitu kabupaten Bogor yaitu pada tahun 2017 sebesar 5.71 juta, tahun 20185.84 juta, dan tahun 2019 sebesar 5,95 juta. Sedangkan jumlah penduduk terendah yaitu kota banjar dimana pada tahun 2017 sebesar 182, 388, pada tahun 2018 sebesar 182,819 dan pada tahun 2019 sebesar 183,110. Jiwa. Pada tahun 2018 Kenaikan tertinggi pada kabupaten Bekasi sebesar 130.884 jiwa sedangkan terendah pada kota banjar sebesar 421 jiwa. Sedangkan pada tahun 2019 kenikan tetap di dominasi kabupaten Bekasi sebesar 132.979 jiwa dan kota banjar sebesar 291 jiwa. 
Vol 1, No. 2 (2020), Desember 2020

E-ISSN: 2746-2471, DOI:

\section{Gambaran Angkatan Kerja}

Dari hasil penelitian, didapatkan data Tingkat Partisipasi Angkatan Kerja (TPAK) di Jawa Barat yang dapat dilihat dari tabel berikut :

Tabel 2. Tingkat Partisipasi Angkatan Kerja Jawa Barat, 2017-2019

\begin{tabular}{lrcc}
\hline \multirow{2}{*}{ Wilayah Jawa Barat } & \multicolumn{3}{c}{ TPAK Kabupaten/Kota (Persen) } \\
\cline { 2 - 4 } & $\mathbf{2 0 1 9}$ & $\mathbf{2 0 1 8}$ & $\mathbf{2 0 1 7}$ \\
\hline Provinsi Jawa Barat & 65.07 & 62.92 & 63.34 \\
Bogor & 65.42 & 62.71 & 64.07 \\
Sukabumi & 62.68 & 62.72 & 63.75 \\
Cianjur & 66.14 & 60.32 & 58.28 \\
Bandung & 65,38 & 61,89 & 62,81 \\
Garut & 62,70 & 60,13 & 62,92 \\
Tasik Malaya & 66,66 & 64,23 & 63,46 \\
Ciamis & 67,56 & 66,85 & 70,10 \\
Kuningan & 61,31 & 58,65 & 57,69 \\
Cirebon & 65,38 & 61,85 & 61,25 \\
Majalengka & 67,97 & 65,76 & 66,11 \\
Sumedang & 63,98 & 62,01 & 62,06 \\
Indramayu & 67,89 & 65,04 & 63,66 \\
Subang & 67,88 & 64,41 & 66,60 \\
Purwakarta & 63,93 & 63,19 & 63,16 \\
Kerawang & 63,62 & 63,19 & 64,94 \\
Bekasi & 64,03 & 64,77 & 61,26 \\
Bandung Barat & 62,09 & 61,46 & 61,73 \\
Pengandaran & 75,18 & 61,34 & 79,88 \\
Kota Bogor & 63,73 & 77,91 & 61,13 \\
Kota sukabumi & 62,56 & 63,21 & 59,24 \\
Kota Bandung & 65,98 & 61,98 & 63,11 \\
Kota Cirebon & 62,84 & 68,03 & 66,45 \\
Kota Bekasi & 65,70 & 65,30 & 64,35 \\
Kota Depok & 65,03 & 62,64, & 64,04 \\
Kota Cimahi & 63,39 & 64,49 & 65,33 \\
Kota Tasik Malaya & 65,38 & 62,75 & 63,88 \\
Kota Banjar & 67,69 & 65,09 & 64,78 \\
\hline Sumber : Badan Pusat & 2020 & &
\end{tabular}

Sumber : Badan Pusat Statistik. 2020 


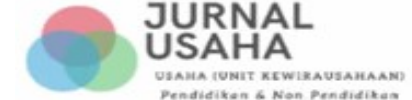

Vol 1, No. 2 (2020), Desember 2020

E-ISSN: 2746-2471, DOI:

Tabel 3.Tabel kenaikan dan penurunan TPAK

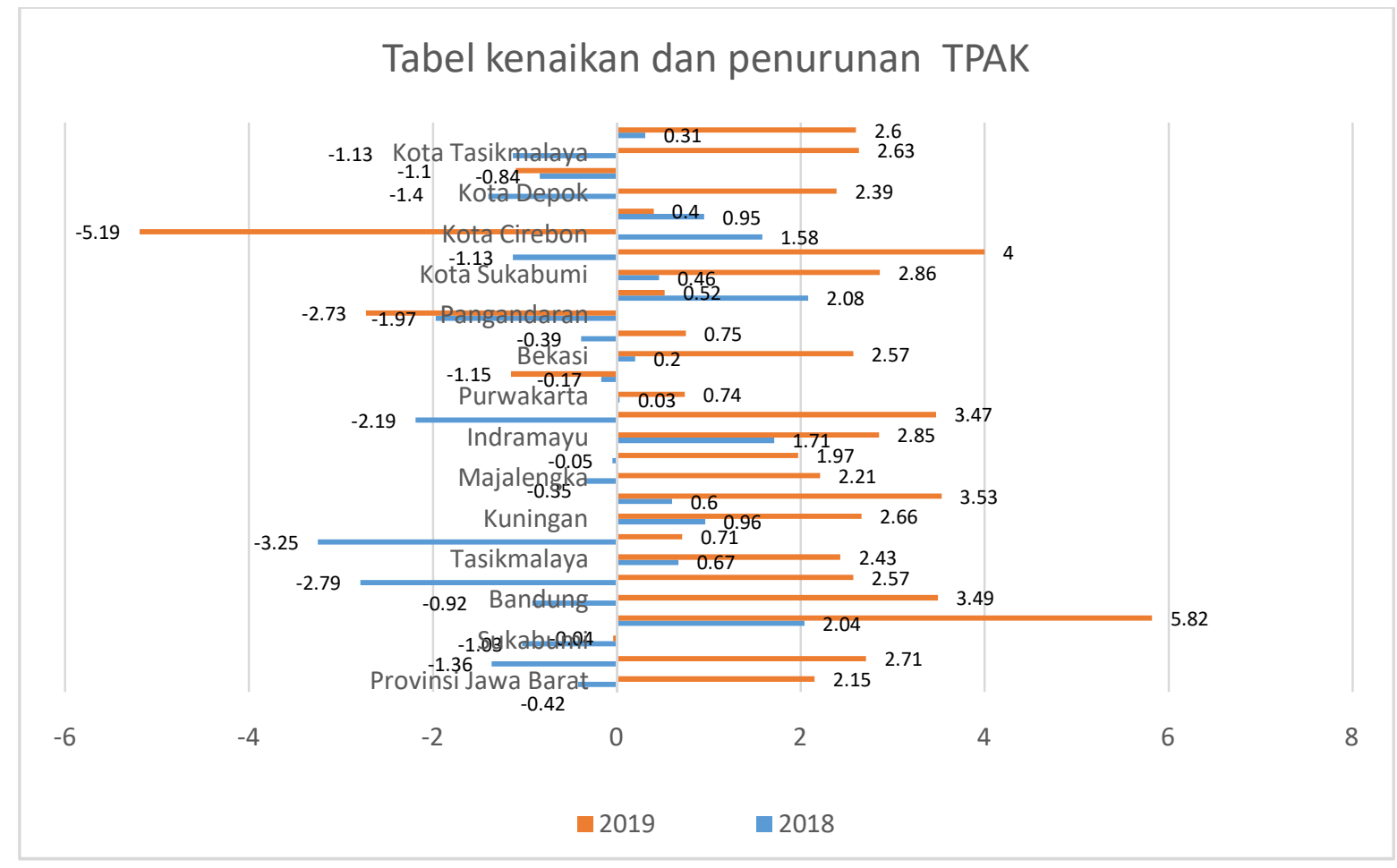

Berdasarkan data diatas terlihat bahwa Jumlah Tingkat Partisipasi Angkatan kerja Jawa Barat pada tahun 2017 sebesar 63,34 . Tahun 2018 sebesar 62,92 mengalami penurunan 0,42 dan pada tahun 2019 TPAK sebesar 65,07 sehingga mengalami kenaikan sebesar 2.15. Partisipasi angkatan kerja terbanyak tertinggi yaitu kabupaten Pengandaran dimana pada tahun 2017 sebesar 79.88, tahun 2018 sebanyak 77.91 juta, dan tahun 2019 sebesar 75.18. Sedangkan jumlah partisipasi angkatan kerja terendah yaitu kota kuningan dimana pada tahun 2017 sebesar 57,69 pada tahun 2018 sebesar 58,65 dan pada tahun 2019 sebesar 61,31 . sedangkan kenaikan TPAK tertinggi pada tahun 2018 yaitu kabupaten Bogor sebesar 2.08 sedangkan terendah tahun 2018 yaitu kabupaten Bekasi sebesar 0.02. pada tahun 2019 kenaikan TPAK tertingi yaitu kabupaten cianjur sebesar 5.82 sedangkan Kabupaten Sukabumi justru mengalami terendah dengan angka penurunan sebesar $0.04 \%$

\section{Penyerapan Tenaga Kerja Bidang Industri di Jawa Barat}

Dari data Penyerapan Tenaga Kerja di Bidang Industri di jawa barat yang dapat dilihat dari tael berikut :

Tabel 4 . Penyerapan Tenaga Kerja di Bidang Induatri Jawa Barat, 2017-2019

\begin{tabular}{lrrr}
\hline Wilayah Jawa Barat & $\begin{array}{c}\text { Tenaga Kerja } \\
\text { Mikro dan Kecil }\end{array}$ & $\begin{array}{c}\text { Tenaga Kerja } \\
\text { menengah dan Besar }\end{array}$ & $\begin{array}{c}\text { Jumlah Tenaga kerja } \\
\text { UMKM dan Besar }\end{array}$ \\
\hline Provinsi Jawa Barat & $1,455,352$ & $2,268,064$ & $3,723,416$ \\
Bogor & 90,074 & 197,188 & 287,262 \\
Sukabumi & 70,333 & 195,386 & 265,719 \\
Caianjur & 72,924 & 25,263 & 98,187 \\
\hline
\end{tabular}


Vol 1, No. 2 (2020), Desember 2020

E-ISSN: 2746-2471, DOI:

\begin{tabular}{lrrr}
\hline Bandung & 87,342 & 232,851 & 320,193 \\
Garut & 93,688 & 25,434 & 119,122 \\
Tasikmalaya & 98,103 & 10,083 & 108,186 \\
Ciamis & 58,805 & 6,963 & 65,768 \\
Kuningan & 16,068 & 5,464 & 21,532 \\
Cirebon & 163,478 & 40,132 & 203,610 \\
Majalengka & 53,577 & 50,327 & 103,904 \\
Sumedang & 39,299 & 88,179 & 127,478 \\
Indramayu & 48,997 & 5,127 & 54,124 \\
Subang & 66,072 & 65,960 & 132,032 \\
Purwakarta & 14,580 & 109,279 & 123,859 \\
Kerawang & 51,649 & 213,541 & 265,190 \\
Bekasi & 63,586 & 588,010 & 651,596 \\
Bandung Barat & 37,152 & 51,578 & 88,730 \\
Pangandaran & 54,649 & 241 & 54,890 \\
Kota Bogor & 38,399 & 19,449 & 57,848 \\
Kota Sukabumi & 9,748 & 2,962 & 12,710 \\
Kota Bandung & 65,132 & 94,731 & 159,863 \\
Kota Cirebon & 8,652 & 8,684 & 17,336 \\
Kota Bekasi & 33,114 & 90,201 & 123,315 \\
Kota Depok & 29,014 & 38,900 & 67,914 \\
Kota Cimahi & 27,457 & 86,415 & 113,872 \\
Kota Tasikmalaya & 52,958 & 9,173 & 62,131 \\
Kota Banjar & 10,502 & 6,543 & 17,045 \\
\hline Sut & & & \\
\hline
\end{tabular}

Sumber : Badan Pusat Statistik.2020

Berdasarkan data diatas terlihat bahwa Jumlah tenaga kerja yang terserap di sektor Industrisebesar 3. 723, 416 terdiri dari Industri Mikro dan kecil sebesar 1.455.352 dan Industri Besar dan sedang sebesar 2, 268064 . Untuk Penyerapan industry Mikro dan Kecil dengan jumlah penyerapan terkecil pada kota Cirebon dengan angka 8.652, sedangkan penyerapan tenaga kerja terbesar pada sedangkan usaha menengah dan besar dengan angka terkecil yaitu kabupaten penggandaran dengan angka 241. Penyerapan Tenaga kerja terbesar unit Mikro dan kecil masih di dominasi Kabupaten Cirebon dengan total 163,478 dan untuk menengah dan besar kabupaten Bekasi dengan angka 588,010 Tenaga Kerja.

\section{Usaha Mikro, Kecil dan Menengah dan Besar di Jawa barat}

Data Usaha Mikro, kecil Menengah dan Besar di Jawa Barat bisa di lihat pada tabel di bawah ini

Tabel 5. Usaha Mikro, kecil Menengah dan Besar di Jawa Barat 2017-2019

\begin{tabular}{cccc}
\hline $\begin{array}{c}\text { Wilayah Jawa } \\
\text { Barat }\end{array}$ & $\begin{array}{c}\text { Usaha Mikro } \\
\text { kecil }\end{array}$ & $\begin{array}{c}\text { Usaha menengah } \\
\text { besar }\end{array}$ & Total Industri M + B \\
\hline
\end{tabular}




\begin{tabular}{|c|c|c|c|}
\hline $\begin{array}{l}\text { Vol 1, No. } 2 \text { (2020), Desember } 2020 \\
\text { E-ISSN: } 2746-2471 \text {, DOI: }\end{array}$ & & & \\
\hline Provinsi Jawa Barat & 574,175 & 10,099 & 584,274 \\
\hline Bogor & 26,793 & 897 & 27,690 \\
\hline Sukabumi & 33,062 & 328 & 33,390 \\
\hline Caianjur & 26,573 & 86 & 26,659 \\
\hline Bandung & 32,171 & 1,565 & 33,736 \\
\hline Garut & 35,640 & 160 & 35,800 \\
\hline Tasikmalaya & 55,002 & 58 & 55,060 \\
\hline Ciamis & 26,609 & 99 & 26,708 \\
\hline Kuningan & 7,261 & 62 & 7,323 \\
\hline Cirebon & 42,972 & 471 & 43,443 \\
\hline Majalengka & 28,533 & 102 & 28,935 \\
\hline Sumedang & 19,574 & 126 & 19,700 \\
\hline Indramayu & 18,601 & 83 & 18,684 \\
\hline Subang & 17,909 & 111 & 18,020 \\
\hline Purwakarta & 7,771 & 268 & 8,039 \\
\hline Kerawang & 14,206 & 724 & 14,930 \\
\hline Bekasi & 28,330 & 2,503 & 30,833 \\
\hline Bandung Barat & 13,388 & 284 & 13,672 \\
\hline Pangandaran & 33,381 & 9 & 33,390 \\
\hline Kota Bogor & 15,275 & 97 & 15,372 \\
\hline Kota Sukabumi & 3,524 & 20 & 3,544 \\
\hline Kota Bandung & 20323 & 701 & 21,024 \\
\hline Kota Cirebon & 3,203 & 57 & 3,260 \\
\hline Kota Bekasi & 10,769 & 486 & 11,255 \\
\hline Kota Depok & 12,159 & 173 & 12,332 \\
\hline Kota Cimahi & 10,160 & 236 & 10,396 \\
\hline Kota Tasikmalaya & 26,500 & 81 & 26,581 \\
\hline Kota Banjar & 4,486 & 12 & 4,498 \\
\hline
\end{tabular}

Sumber : Badan Pusat Statistik. 2020

Berdasarkan data diatas terlihat bahwa Jumlah UMKM dan Industri Besar sebesar 584. 274 terdiri dari Industri Mikro dan kecil sejumlah 574,175 dan Industri Besar dan sedang sebesar 10,099. Untuk industry Mikro dan Kecil dengan jumlah terkecil pada kota Cirebon dengan angka 3203 dan terbesar pada kota tasik Malaya sebesar 55,002, sedangkan usaha menengah dan besar dengan angka terkecil yaitu kabupaten penggandaran dengan angka 9. Penyerapan untuk menengah dan besar Bekasi dengan angka 2.503 Kota Bekasi.

\section{E. SIMPULAN}

Simpulan dalam penelitian ini yaitu penduduk Jawa Barat pada tahun 2017 sebesar 48, 03 jt, tahun 2018 sebesar 48,68 juta dan tahun 2019 sebesar 49,16 juta ini mengalami peningkatan dalam 3 tahun. Penduduk terbanyak yaitu kabupaten Bogor yaitu pada tahun 2017 sebesar 5.71 juta, tahun 20185.84 juta, dan tahun 2019 sebesar 5,95 juta. Sedangkan jumlah penduduk terendah yaitu kota banjar dimana pada tahun 2017 sebesar 182,388 , pada tahun 2018 sebesar 182,819 dan pada tahun 2019 183,110. 
Tingkat Partisipasi Angkatan kerja Jawa Barat pada tahun 2017 sebesar 63,34 . Tahun 2018 sebesar 62,92 mengalami penurunan 0,42 dan pada tahun 2019 TPAK sebesar 65,07 sehingga mengalami kenaikan sebesar 2.15. Partisipasi angkatan kerja terbanyak tertinggi yaitu kabupaten Pengandaran dimana pada tahun 2017 sebesar 79.88, tahun 2018 sebanyak 77.91 juta, dan tahun 2019 sebesar 75.18. Sedangkan jumlah partisipasi angkatan kerja terendah yaitu kota kuningan dimana pada tahun 2017 sebesar 57,69 pada tahun 2018 sebesar 58,65 dan pada tahun 2019 sebesar 61,31 . sedangkan kenaikan TPAK tertinggi pada tahun 2018 yaitu kabupaten Bogor sebesar 2.08 sedangkan terendah tahun 2018 yaitu kabupaten Bekasi sebesar 0.02. pada tahun 2019 kenaikan TPAK tertingi yaitu kabupaten cianjur sebesar 5.82 sedangkan Kabupaten Sukabumi justru mengalami terendah dengan angka penurunan sebesar $0.04 \%$. Jumlah tenaga kerja yang terserap di sektor Industri sebesar 3. 723, 416 terdiri dari Industri Mikro dan kecil sebesar 1.455.352 dan Industri Besar dan sedang sebesar 2, 268064.

Untuk Penyerapan industry Mikro dan Kecil dengan jumlah penyerapan terkecil pada kota Cirebon dengan angka 8.652, sedangkan usaha menengah dan besar dengan angka terkecil yaitu kabupaten penggandaran dengan angka 241. Penyerapan Tenaga kerja terbesar unit Mikro dan kecil masih di dominasi Kabupaten Cirebon dengan total 1,455, 352 dan untuk menengah dan besar Bekasi dengan angka 2,268,064. Jumlah UMKM dan Industri Besar sebesar 584. 274 terdiri dari Industri Mikro dan kecil sejumlah 574,175 dan Industri Besar dan sedang sebesar 10,099. Untuk industry Mikro dan Kecil dengan jumlah terkecil pada kota Cirebon dengan angka 3203 dan terbesar pada kota tasik Malaya sebesar 55,002, sedangkan usaha menengah dan besar dengan angka terkecil yaitu kabupaten penggandaran dengan angka 9. Penyerapan untuk menengah dan besar Bekasi dengan angka 2.503 Kota Bekasi.

Dengan adanya laju penduduk semakin pesat, angkatan kerja yang tinggi diharapkan pemerintah daerah mampu membangun cluster cluster usaha baru yang bisa menyerap tenaga kerja dan memberikan pelatihan pelatihan yang dibutuhkan sesuai kemampuan dan mengembangkan produk local bisa bersaing dalam pasar International. 


\section{DAFTAR PUSTAKA}

Agustina, E., Syechalad, M. N., \& Hamzah, A. (2019). Pengaruh Jumlah Penduduk, Tingkat Pengangguran Dan Tingkat Pendidikan Terhadap Kemiskinan Di Provinsi Aceh. Jurnal Perspektif Ekonomi Darussalam, 4(2), 265-283. https://doi.org/10.24815/jped.v4i2.13022

Arsyad, lincolin. (2004). Ekonomi Pembangunan. Edisi Keempat. STIE YKPN.Yogyakarta. STIE YKPN.Yogyakarta.

BPS. (n.d.). Badan Pusat Statistik.

Didu, S., \& Fauzi, F. (2016). Pengaruh Jumlah Penduduk, Pendidikan Dan Pertumbuhan Ekonomi Terhadap Kemiskinan Di Kabupaten Lebak. Jurnal Ekonomi-Qu, 6(1), 102117. https://doi.org/10.35448/jequ.v6i1.4199

Hafni, R., \& Rozali, A. (2017). Analisis Usaha Mikro, Kecil, dan Menengah (umkm) terhadap Penyerapan Tenaga Kerja di Indonesia. Ilmu Ekonomi Dan Studin Pembangunan, 15(2), 77-96. Retrieved from http://jurnal.umsu.ac.id/index.php/ekawan/article/view/1034/pdf_58

Husein Umar. (2001). Metode Penelitian dan Aplikasi dalam Pemasaran. Jakarta: PT Gramedia.

Kuncoro. (2002). Dasar-Dasar Analisis Kemiskinan. Jakarta.: Grapindo Persada.

Nawawi \& Martini. (1996). Penelitian Terapan. Yogyakarta: GajahMada UniversityPress,cet .2.

Sadono Sukirno. (2002). Pengantar Ekonomi Miroekonomi (ketiga). PT Raja Grafindo Persada.

Sugiyono. (2010). Metode Penelitian Pendidikan Pendekatan Kuantitatif, kualitatif, dan $R \& D$. Bandung: Alfabeta. 